\title{
ERRATUM
}

\section{ROCHESTER'S BRONZE SCRAG AND PEARL NECKLACE: BRONZED MASCULINITY IN JANE EYRE, SHIRLEY, AND CHARLOTTE BRONTË'S JUVENILIA-ERRATUM}

\author{
By Judith E. Pike
}

doi:10.1017/S1060150312000381, Published by Cambridge University Press, 26 March 2013

In this article, the 3rd sentence (on the first page) is not grammatically correct. We are reproducing the paragraph for completeness.

IN THE PAST TWENTY YEARS, GIVEN THE burgeoning field of postcolonial studies and its inquiry into the identity politics of race, ethnicity, and imperialism, significantly more critical attention has been paid to Charlotte Brontë's portrayal of Bertha Rochester in Jane Eyre (1847) than in the prior one hundred and forty years of Brontë scholarship. While in The Madwoman and the Attic (1979), Gilbert and Gubar present an earlier reading of Bertha as "Jane's truest and darkest double" (360), any reading of Bertha's darkest in terms of a cultural or racialized identity came about in later criticism. Gayatri Spivak was instrumental in positioning Bertha within a discourse of imperialism rather than reading her merely in psychological terms, which then precipitated more recent studies on Bertha's colonial heritage, her financial and cultural imperialist inheritance and her ambiguous ethnic status as a Creole woman. ${ }^{1}$ Contemporary critics have also addressed how Rochester in a sense becomes Bertha's "truest and darkest double." However, his darkness has proven to be far more quizzical, for unlike Bertha he is neither Creole nor raised in the West Indies; quite to the contrary, Rochester was desired by the Masons precisely because of his heritage, being "of a good race." 2 Still, as readers, we have had to grapple with Brontë's numerous descriptions of Rochester's dark visage. 


\section{Work Cited}

Pike, Judith. "Rochester's Bronze Scrag and Pearl Necklace: Bronzed Masculinity in Jane Eyre, Shirley, And Charlotte. Brontë's Juvenilia." Victorian Literature and Culture (2013). doi:10.1017/ S1060150312000381. 